\title{
What, after all, was Heidegger about?
}

\author{
Thomas Sheehan ( \\ Stanford University
}

\begin{abstract}
The premise is that Heidegger remained a phenomenologist from beginning to end and that phenomenology is exclusively about meaning and its source. The essay presents Heidegger's interpretation of the being (Sein) of things as their meaningful presence (Anwesen) and his tracing of such meaningful presence back to its source in the clearing, which is thrown-open or appropriated ex-sistence (das ereignete/geworfene Da-sein).

The essay argues five theses: (1) Being is the meaningful presence of things to man. (2) Such meaningful presence is the Befragtes of Heidegger's question, not the Erfragtes. (3) Being and Time's goal was to articulate the openness that allows for all meaningfulness. (4) Ereignis - the appropriation of exsistence to sustaining the clearing - is the later Heidegger's reinscription of thrown-openness, der geworfene Entwurf. (5) Appropriated thrown-openness, as the clearing, is intrinsically hidden, i.e., unknowable.
\end{abstract}

\section{Some preliminaries:}

(1) I cite Heidegger's texts by page and line (the line-number follows the period) in both the Gesamtausgabe and the current English translations where available, all of which are listed in the bibliography at the end of this issue of the journal. I cite Sein und Zeit in the Niemeyer 11th edition and in the ET by Macquarrie-Robinson.

(2) Sinn and Bedeutung are closely related, although Sinn is broader than Bedeutung. Sinn refers either to intelligibility as such or to the fact of something being intelligible, whereas Bedeutung is the specific meaning that a thing has. Sinn as intelligibility is generally interchangeable with Bedeutsamkeit and Verständlichkeit. Thus I translate Sinn as "intelligibility" or "meaningfulness." Sinn in turn allows for Bedeutung as the particular meaning of a specific thing.

(3) I take "intellect" in the broad sense of voṽ $\varsigma$ and in the specific sense of $\lambda$ ó $\gamma$ o $\varsigma$ understood as discursive intellect, whether practical or theoretical.

(4) Dasein is translated as "existence" (= existentiel), and Existenz or Da-sein as "ex-sistence" (= existential). The word "man" refers to human being, not the male of the species. I render das Seiende as "beings," "things," and "entities" ex aequo. "Man" refers to human beings in general, not to the male of the species. 
What, after all, was Heidegger about?

Let's step back for a moment - way back - and ask: What was the final goal of Heidegger's thinking? What was he ultimately after?

Was his goal "being," das Sein? Or was it something "being-er than being" (wesender als das Sein)?" And might that be "being itself," das Sein selbst, sometimes written as Seyn? Or was it rather, as Heidegger says, Seyn qua Seyn - and if so, what might that mean? ${ }^{2}$ Again: Was Heidegger's main topic die Wesung der Wahrheit des Seyns? ${ }^{3}$ or was it die Wahrheit der Wesung des Seyns? ${ }^{4}$ Or was his topic Anwesung, "presencing"? Or the Lichtung? Or Ereignis as just another name for Being Itself? Or was it, rather, Enteignis? $?^{5}$ Or $\dot{\alpha} \lambda \eta \dot{\eta \varepsilon} \alpha$ ? or perhaps the $\Lambda \eta \eta \eta$ that lurks within $\alpha \lambda \eta \dot{\vartheta \varepsilon ı} \alpha ?^{6}$ Or was it the ontological difference, as some scholars hold? ${ }^{7}$ Or do all of these point to the same thing? And how exactly are we to distinguish (if we are to distinguish) one from the other?

There is, in fact, considerable confusion at the heart of the Heideggerian enterprise, and it may not be the fault of Heidegger scholars. Just to stay with the term Sein: Heidegger himself said that "it remains unclear what we are supposed to think under the name "being." "A Are Heideggerians, then, subject to the Master's judgment: “They say ' $i s$ ' without knowing what 'is' actually means"? ${ }^{9}$ In any case, he may have known what he meant by the word Sein, but he didn't always make that clear to the rest of us. So we might want to make our own the plea that the

\footnotetext{
${ }^{1}$ GA 73, 2: 1319.23 .

2 GA 73, 2: 997: "Seyn ist nicht Seyn." Further on Seyn: ibid., 968.7; 1033.10; 1039.10; 1122.7; etc.; also GA 9: 306 (g)/374 (a): "Seyn ist . . das Ereignis." But cf. loc. cit., "Sein qua Ereignis." At GA 81: 76.18, Sein and Seyn are equated, but at GA 76: 49.15-9 they are contrasted. ${ }^{3}$ GA $65: 73.21=58.35-6$.

${ }^{4}$ GA $65: 78.26=63.4-5$.

${ }^{5}$ GA 2: 252, note $\mathrm{a}=183.44$; GA 11: 59, note 33; GA 76: 5.25.

${ }^{6}$ GA 6, 1: $197.9=194.1$.

7 "[The difference between being and beings] is the central thought of Heideggerian philosophy": Haugland (2000, I, 47).

${ }^{8}$ GA $40: 34.31-2=34.16-7$.

${ }^{9}$ GA $15: 277.17-8=5.7-8$.
} 
Eleatic Stranger expresses in the Sophist: "So first teach us this very thing lest we seem to know what you told us when in fact we don't"' (244a8-b1).

In the spirit of a medieval disputatio I propose to state and defend five theses in support of a paradigm shift in how to read Heidegger. This is an attempt to "make sense" of Heidegger, where I mean that phrase as a bit of a pun. I make sense of Heidegger by first of all following him in his crucial phenomenological reinterpretation of the being of beings (das Sein des Seienden) as the meaningful presence of things to man (das Anwesen des Anwesenden). "Being" is usually and

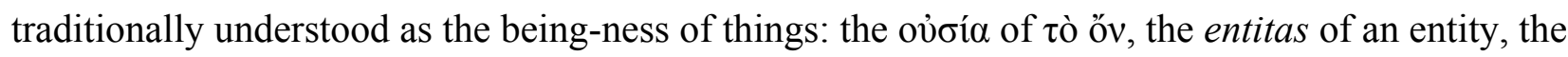
realness of the real. (I use the word "realness" in what Heidegger calls its traditional sense of existentia as objective presence: Vorhandenheit. ${ }^{10}$ However, Heidegger reinterprets all of that, including his own use of "the being of beings," in a phenomenological mode such that being-quabeingness ${ }^{11}$ comes out not as the ontological realness of the real but as the Anwesen of things, their presence to man. However, such Anwesen is not mere objective presence nor simply presence to our five senses ${ }^{12}$ but rather das daseinsmäßige Anwesen - the meaningful presence of things in conjunction with existence's understanding of Anwesen/Sein/meaningfulness. It follows, therefore, that the being of things is their intelligibility, their $\alpha \lambda \eta \emptyset q \varepsilon \alpha$ taken broadly. See, for example, Heidegger's equation of Sein and intelligibility when he speaks of "the inquiry into the intelligibility of things [Sinn des Seienden], that is, the inquiry into being [Sein]." ${ }^{13}$ Or when he designates Sein as "the intelligibility [Sinn]" of phenomena. ${ }^{14}$ Or when he speaks of ontology as "the explicit theoretical question about the intelligibility [Sinn] of things.",

However, I argue that this is only the first step. Heidegger's project finally makes sense only when we realize that his ultimate goal was the source of intelligibility, "die Herkunft von

\footnotetext{
${ }^{10} \mathrm{SZ} 211.22-7=254.28-33$.

${ }^{11}$ GA 66: 316.26-7 = 281.32-3: “Anwesung und d.h. Sein und d.h. Seiendheit." Also GA 74: 6.3.

${ }^{12}$ Cf. SZ 33.30-2 = 57.11-3.

${ }^{13}$ GA 19: 205.13-4 = 141.33-4.

${ }^{14} \mathrm{SZ} 35.25=59.31$.

${ }^{15} \mathrm{SZ} 12.14-5=32.23-4$. This text has stood through some seventeen editions of SZ (thirteen of them during Heidegger's lifetime). But GA 2, which claims to be the "unveränderter Text," changes it without notice at $16.23=11.15$ to "nach dem Sein des Seienden."
} 
Anwesen." 16 This source he denominated as "die ereignete Lichtung," ${ }^{, 17}$ the appropriated or thrown-open "space" for possible intelligibility, which ex-sistence sustains and as such is. This clearing makes it possible for us to take Socrates as an Athenian, or this tool as suitable for that task, and thus to make sense of Socrates and the tool (traditionally, "to understand their Sein").

The premise of this essay is that Heidegger remained a phenomenologist from beginning to end and that phenomenology is exclusively about meaningfulness and its source. As Aron Gurwitsch pointed out years ago, once one has taken the phenomenological turn (the sine qua non of phenomenological work) "there are no other philosophical problems except those of sense, meaning, and signification." ${ }^{18}$ In short, this essay is about Heidegger's phenomenological reinterpretation of das Sein des Seienden as the significance of things, and his further tracing of such significance back to its source in appropriation.

\section{Being (das Sein des Seienden) is the meaningful presence of things to man.}

Heidegger puts a twist on the word Sein and finally sets it aside. "I no longer like to use the word 'Sein"' he said. ${ }^{19}$

"Sein" remains only the provisional term. Consider that "Sein" was originally called "presence" [Anwesen] in the sense of a thing's staying-here-before-us-in-disclosedness. ${ }^{20}$

"Staying-here-before-us-in-disclosedness" (her-vor-währen in die Unverborgenheit) is Heidegger's term of art for the meaningful presence of something to someone. The phrase expresses three things: (1) the relative stability and constancy of the meaningful thing (währen);

${ }^{16}$ GA $6: 2,304.11=201.13-5$. See GA 2: 53 note $\mathrm{a}=37$ note $\uparrow ;$ GA 10: $131.19-20$ and $.28=$ 88.27 and .34 ; and GA 73, 2: 984.2 .

${ }^{17}$ GA $71: 211.8$.

${ }^{18}$ Gurwitsch (1947, p. 652). Italicized in the original.

${ }^{19}$ GA 15: $20.8-9=8.34$.

${ }^{20}$ GA $7: 234.13-7=78.21-4$. 
(2) the locus of its meaningful appearance, namely the world of human concerns (-vor-); and (3) a certain movement into appearance, a thing's being brought from an undisclosed but potential intelligibility into an actually operative one (in die Unverborgenheit). This disclosedness of a thing to understanding is its meaningfulness.

If we overlook the phenomenological paradigm within which Heidegger works, we risk reducing his texts to some form of naïve realism in which Sein can somehow show up without human existence - in the Jurassic Period, for example, some 150,000,000 years ago. It is wrong to think that Heidegger refused the phenomenological reduction and conducted his early investigations within the natural attitude. Husserl thought that to be the case and accused Heidegger of not understanding the phenomenological reduction. To be sure, Heidegger did not understand this reduction as leading things back to "the transcendental life of consciousness and its noetic-noematic experiences, in which objects are constituted as correlates of consciousness. ${ }^{21}$ Rather, it meant

leading the phenomenological vision back from the apprehension of a thing, whatever may be the character of the apprehension, to the understanding of the being [Sein] of the thing: understanding the thing in terms of the way it is disclosed. ${ }^{22}$

Note that this being (Sein) to which we lead a thing back is "the way the thing is disclosed," that is, the way in which it is meaningfully present to us and our concerns. Heidegger's phenomenological reduction "puts the breaks on" (cf. epoché) our natural tendency to overlook meaning, to look through it to the entity. The reduction leads us back reflectively and thematically to where we always already stand: in relation to the thing in terms of its significance to us - but not to us as some transcendental consciousness but rather as living in the world among things as a

${ }^{21}$ GA $24: 29.12-5=21.24-6$.

${ }^{22}$ GA 24: 29.15-9 = 21.27-30, my emphasis. Cf. GA 20: 423.4-5 = 306.29-30. Re "understanding": GA 16: 424.21-2 = 5.15-6: "Verstehen, d.h. Entwerfen." 
body. Heidegger's phenomenological reduction is a matter of learning to stand thematically where we always already stand without noticing it.

Of course neither Husserl nor Heidegger doubt that things remain independent of our thinking after the reduction. Husserl explicitly said that

we must not overlook the most essential thing of all, namely that even after the purifying epoché, perception still remains perception of this house, indeed, of this house with the accepted status of "actually existing.",23

And for Heidegger “Questions like 'Does the world exist independent of my thinking?' are meaningless." ${ }^{, 24}$ He added that the thing in nature

shows up in the reducing gaze that focuses on the act of perceiving, because this perceiving is essentially a perceiving of the thing. The thing belongs to the perceiving as its perceived. ${ }^{25}$

For Heidegger as well as for Husserl, things are still "out there" after the reduction. It's just that as such they are not phenomenologically interesting. The subject matter of a phenomenological inquiry is things only insofar as we are in some way meaningfully engaged with them. After the reduction, the only philosophical problems one may properly pursue are those of intelligibility and meaning: hermeneutical questions.

From the beginning - that is, in his phenomenological re-reading of Aristotle in the 1920s - Heidegger interpreted the Greek word ov̉øía not in terms of the objective presence of things but rather in terms of their presence to human interests and concerns. An ov่oía is what belongs to a

\footnotetext{
${ }^{23}$ Husserl (1968) 243.30-4 = Husserl (1997) 91.12-4.

${ }^{24}$ GA 58: 105.15-6 = 84.5-6. See GA 26: 194.30-1 = 153.28-9.

${ }^{25}$ Husserl (1968) 261.6-9 = Husserl (1997) 113.13-5.
} 
person, one's stable possessions or holdings, something that one has a stake in. (Compare John Locke's “to have a property in something.") ${ }^{26}$ As Heidegger later put it:

In Greek ov่бí $\alpha$ means beings - not just any beings but beings that are in a certain way exemplary in their being, namely the beings that belong to one, one's goods and possessions, house and home (what one owns, one's wealth), what is at one's disposal. ...

What makes them exemplary? Our goods and possessions are invariantly within our reach. Ever at our disposal, they are what lies close to us, they are right here, presented on a platter, they steadfastly present themselves. They are the closest to us, and as steadfastly closest, they are in a special sense at-hand, present before us, present to us. ${ }^{27}$

Heidegger spelled out this insight by interpreting the presence of things as their meaningfulness, a theme that runs through all his work, beginning with his courses in the 1920s and continuing right through Being and Time and up to the end.

[T]o live means to care. What we care for and about, what care adheres to, is equivalent to what is meaningful. Meaningfulness is a categorial determination of the world; the objects of a world "worldly" or "world-some" objects - are lived inasmuch as they embody the character of meaningfulness. ${ }^{28}$

We do not first have a dumb encounter with things and only later assign them meanings.

It is not the case that objects are at first present as bare realities, as objects in some sort of natural state and that then in the course of

\footnotetext{
${ }^{26}$ Locke (2003, p. 111).

${ }^{27}$ GA 31: 51.11-5 and 51.31-4 = 36.8-11 and .21-5.

${ }^{28}$ GA 61: 90.7-12 = 68.6-10.
} 
our experience they receive the garb of a value-character so that they do not have to run around naked. ${ }^{29}$

Rather, what is primary and what is immediately given to us without some mental detour through a conceptual grasp of the thing is the meaningful [das Bedeutsame]. When we live in the first-hand world around us, everything comes at us loaded with meaning, all over the place and all the time. Everything is within the world [of meaningfulness]: the world holds forth. ${ }^{30}$

Which means: If beings are the meaningful (das Bedeutsame), their being is their meaningfulness (Bedeutsamkeit).

All of us, he says, whether a philosophy student, a farmer from the Black Forest, or someone from a tribe remote from Western civilization, always see what we encounter "as fraught with a meaning." 31

One must put aside all theorizing and not drag in what epistemologists say about the matter. Instead, see the sense in which factical experience ever and anew has what it experiences in the character of meaningfulness. Even the most trivial thing is meaningful (even though it remains trivial nonetheless). Even what is most lacking in value is meaningful. ${ }^{32}$

There is nowhere else for a human being to live except in meaning.

${ }^{29}$ GA $61: 91.22-5=69.6-9$.

${ }^{30}$ GA 56/57: 72.31-73.5 = 61.19-28: "holds forth" = "es weltet."

${ }^{31}$ GA 56/57: 71:29-31 = 60.23-4: "mit einer Bedeutung behaftet."

${ }^{32}$ GA 58: $104.19-24=83.19-23$. 
I live factically always as a prisoner of meaningfulness. And every instance of meaningfulness has its arena of new instances of meaningfulness. . . I live in the factical as in an entirely particular matrix of meaningfulnesses. ... Whatever is factically experienced in factical life-contexts stands in this unobtrusive character of meaningfulness. ${ }^{33}$

Meaningfulness, as a thing's relatedness-to-oneself (Mich-Bezogenheit) ${ }^{34}$ need not be explicit or expressed but can remain quite implicit and unnoticed. "The phenomenon of meaningfulness is not what we originally see." 35 But that in no way speaks against the reality that "factical life lives in factical relations of meaningfulness." ${ }^{36}$ Indeed: "The meaning of "exsistence' lies, in factical life, in forms of meaningfulness, whether actually experienced, or remembered, or awaited." ${ }^{37}$ We do not meet things by taking on board dumb sense data; we always encounter things as something or other, where, in traditional language, the "as-what" and the "how" point to the meaningful presence (Anwesen) of the thing.

The as-what and the how of the encounter may be designated as meaningfulness. This itself is to be interpreted as a category of Sein. $^{38}$

Heidegger enunciates this position again in his lectures and writings of 1924. For example, his course on "Basic Concepts of Aristotelian Philosophy":

For a long time now, I have been designating the ontological character of existence as meaningfulness. This ontological character is the primary one in which we encounter the world. ${ }^{39}$

\footnotetext{
${ }^{33}$ GA 58:104.32-105.1-9 = 83.30-8: "bedeutsamkeitsgefangen."

${ }^{34}$ GA $58: 105.12-3=84.3$.

${ }^{35}$ GA $58: 108.18-9=86.10-1$.

${ }^{36}$ GA 58: 105.22 = 84.10: "in faktischen Bedeutsamkeitsbezügen."

${ }^{37}$ GA $58: 106.12-4=84.31-2$.

${ }^{38}$ GA $63: 93.7-9=71.10-12$.
} 
Or in reading through his essay "The Concept of Time" (1924; the essay meant for publication, not the Marburg address) one can hardly take a step without stumbling over the word Bedeutsamkeit.

The lived world is present not as a thing or object, but as meaningfulness. ${ }^{40}$

We have now identified the basic character of encountering the world: meaningfulness. ${ }^{41}$

We identify meaningfulness as the world's primary ontological

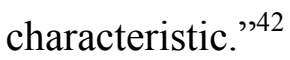

... the primary character of encountering the world meaningfulness. ${ }^{43}$

The following year, on the verge of writing Being and Time, Heidegger again signaled the centrality of meaning to human being in his course on logic and truth. "Because the very nature of existence is to make sense of things, existence lives in meanings and can express itself in and as meanings. ${ }^{, 44}$

Heidegger carried into his major work, Being and Time, this same conviction that Sein is to be understood as the meaningful presence of things. There he designated the structure of world (Welt) as meaningfulness (Bedeutsamkeit), and he referred to Division One's analysis of existence

${ }^{39}$ GA $18: 300.15-8=203.27-9$.

${ }^{40}$ GA $64: 65.18-9=55.15-6$.

${ }^{41}$ GA $64: 23.32-3=17.25-6$.

${ }^{42}$ GA $64: 24.2-3=17.30-1$.

${ }^{43}$ GA $64: .25 .13-4=19.1-2$

${ }^{44}$ GA $21: 151.4-5=127.30-2$. 
as the basis of his doctrine of meaning (Bedeutungslehre). ${ }^{45}$ At the core of that doctrine is the phenomenology of existence as what Heidegger calls "being-in-the-world." But since the essence of world is meaningfulness, we should interpret In-der-Welt-sein more accurately as In-derBedeutsamkeit-sein: the very structure of ex-sistence is its a priori engagement-withmeaningfulness. This is what Heidegger calls our structural "familiarity with meaningfulness." Absent that engagement, we cease to exist: for us there is no hors-texte, no "outside-of-meaning." When we can no longer relate to the meaningfulness of things, we are dead. Our a priori engagement with intelligibility - as our only way to be - entails that we are ineluctably hermeneutical. We necessarily make some sense of everything we meet (even if only interrogative sense), and if we cannot make any sense at all of something, we simply cannot meet it.

Meaningfulness or intelligibility, which is always discursive, is confined to the realm of the human. But how exactly do things become intelligible to us? In Being and Time Heidegger writes: "Intelligibility is an existentiale of existence, not a property attaching to things. ... Existence alone 'has' intelligibility." ${ }^{\text {" } 77}$ But at the same time: "When things within the world are discovered with the being of existence - that is, when they come to be understood - we say they have intelligibility." ${ }^{48}$ That is, we alone have the ability to make sense of things, and we do so by connecting a possibility of something we encounter with a possibility or need of ourselves: we take what we meet in terms of it relation to our everyday concerns and goals. When things are discovered in such a relation with human beings within a given context, they make sense. And world is the concatenation of relations which brings that about.

${ }^{45}$ SZ 87.17-8 = 120.3; 334.33-4 = 384.1; and 166.9-10 = 209.26-7. Cf. GA 64: 24.4-7 = 17.34-5.

${ }^{46}$ SZ 87.19-20 = 120.25: "Vertrautheit mit der Bedeutsamkeit."

${ }^{47}$ SZ 151.34-5=193.11-3. On worldhood as an existential: ibid., 64.19-20 = 92.31-2.

${ }^{48}$ SZ 151.22-4 = 192.35-7. The text continues (151.24-5 = 192.37-193.1): "But strictly speaking what is understood is not the intelligibility but the thing, or alternatively being." The phrase "alternatively being" refers to when Sein rather than das Seiende is the focus of the question, as in Heidegger's Grundfrage. 


\section{THE WORLD AS A REALM OF MEANINGFULNESS}

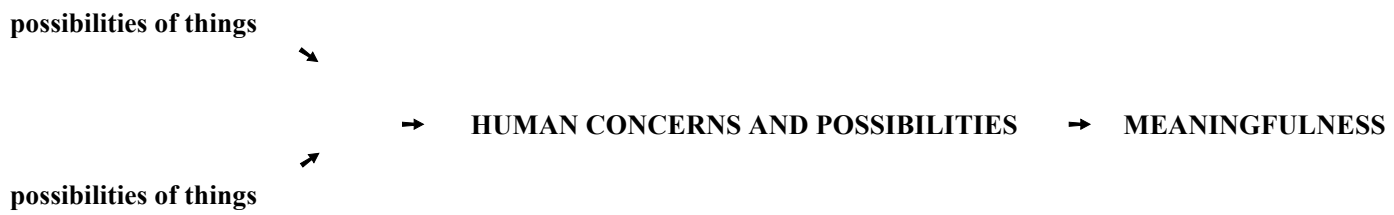

Heidegger says, "As existing, existence is its world." 49 That is, the world is ourselves writ large as the matrix of intelligibility: it is our thrown-openness (Geworfenheit as geworfener Entwurf) structured as a set of meaning-giving relations. The world consists of lines of referral to our concerns (represented by the arrows above) that issue in the meaningfulness of things. We are a hermeneutical field of force, like a magnet that draws things together into unities of sense $\mathrm{e}^{50}$ insofar as these things are connected with a possibility of ourselves as the final reference point.

(Heidegger is clear that the process of making sense of things is, in the broadest terms, social: "Existence in itself is essentially being-with." ${ }^{51}$ However, it must be said that his take on the social in Being and Time is generally negative: see his remarks on the "crowd-self" - das Man-selbst - in $\S 27$ and $\S \S 55-58$ of that work.)

It is quite clear, then, that by das Sein des Seienden Heidegger always means Anwesen, the meaningful presence of something to someone in terms of that person's concerns and interests. Whether early or late, Heidegger never understood such Sein as something "built into" things or as the objective presence of things in space and time. ${ }^{52}$ That was what he called existentia, the ontological substance of things when they are considered apart from human involvement with them - which is to say, before the enactment of a phenomenological reduction. The word Sein in Heidegger is always written under phenomenological erasure, that is, it is always understood as

${ }^{49}$ SZ 364.34-5 = 416.8. See ibid., 64.19-20 = 92.32; $365.38=417.11 ; 380.28-30=432.17-8$. Also GA 9: $154.18-9=120.24-5$ and GA 24: $237.8-10=166.33-5$.

${ }^{50}$ Cf. GA 9: $279.1-7=213.10-15$.

${ }^{51}$ SZ 120.22-3 = 156.31; see ibid., 121.7-8 = 157.14-5.

${ }^{52}$ GA 9: 276.17-9 = 211.16-8: "nicht eine am Stoff vorhandene, seiende Eigenschaft." 
occurring in correlation with existence. This is not the Husserlian correlation of noema and noesis, of meant object and constituting consciousness, but rather the togetherness of Anwesen and Dasein, being-as-meaningfulness and existence. Heidegger finds this insight as far back as

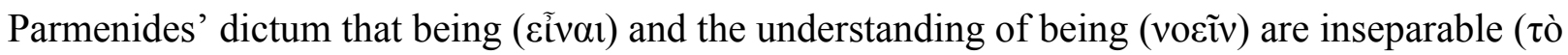
av่ó: fragment 3). The phenomenological point is repeated by Heidegger in a variety of formulations, for example:

Being "is given" only as long as existence $i$ (that is, only as long as an understanding of being is onticly possible). ${ }^{53}$

Being "is" only in the understanding enacted by those entities whose being entails an understanding of being. ${ }^{54}$

[The being-question] asks about being itself insofar as being enters into the intelligibility [Verständlichkeit] of existence. $^{55}$

Being: that which specifically appears only in man. ${ }^{56}$

Being needs ex-sistence and certainly does not occur without this appropriation [of ex-sistence]. ${ }^{57}$

Indeed, in emphasizing that being-as-meaningful-presence can appear only in conjunction with human being, Heidegger even goes so far as to speak, surprisingly, of

the dependence of being on the understanding of being. ${ }^{58}$

${ }^{53}$ SZ 212. $4-5=255.10-1$.

${ }^{54} \mathrm{SZ} 183.29-30=228.12-4$.

${ }^{55} \mathrm{SZ} 152.11-2=193.31-2$.

${ }^{56}$ GA 73, 1: 337. Cf. GA 73, 2: 975.24: "Sein ist nie ohne Offenbarkeit von Seiendem zu Denken."

${ }^{57}$ GA 65: 254.22-3 = 200.23-4: "Seyn ... Da-sein." 
Being is dependent on man. ${ }^{59}$

Being: only from ex-sistence. ${ }^{60}$

\section{Meaningful presence (Anwesen) is the starting point of, but not the answer to, Heidegger's Grundfrage.}

In what sense is Heidegger's basic question, in its traditional ontological formulation, concerned with das Sein selbst, and in what sense is it not? This question has bedeviled Heidegger scholarship from the beginning; and so we must proceed cautiously, step-by-step. Let us begin, then, by asking about the general structure of any question and then go on to apply it to the "guiding question" (Leitfrage) of metaphysics and the "basic question" (Grundfrage) of Heidegger's own work.

The three moments of any question are what Heidegger calls the Befragtes, the Gefragtes, and the Erfragtes. These terms stand for, respectively, the "object," the "optic," and the heuristic "outcome" of the inquiry. ${ }^{61}$

1. The Befragtes or object of a question refers to the thing under investigation, what medieval Scholasticism called the obiectum materiale quod or material object.

2. The Gefragtes or optic refers to the formal focus the inquirer adopts in investigating the material object, and the question that follows from that. ${ }^{62}$

\footnotetext{
${ }^{58}$ SZ 212.13-4 = 255.19-20: "Abhängigkeit des Seins. . . von Seinsverständnis."

${ }^{59}$ GA 66: 139.18 = 119.6: "Das Seyn is vom Menschen abhängig."

${ }^{60}$ GA 66: 138. 32 = 118.24: "Das Seyn nur vom Da-sein.” Also GA 65: 263.28-9 = 207.29-30 and $264.1-2=207.33-4$.

${ }^{61}$ SZ 5.13-7 = 25.19-27. Also GA 88: 12: 12.17-20; 20.12-5; and 23.25-6.

${ }^{62}$ Cf. GA 20: 423.8-11 = 306.33-5: "die Hinsicht; woraufhin es gesehen wird und gesehen werden soll."
} 
3. Finally, the Erfragtes or outcome is a formal indication of the answer the inquirer hopes to obtain by bringing the formal focus to bear on the material object.

With this in mind, we can distinguish metaphysics' guiding question or Leitfrage from Heidegger's meta-metaphysical question or Grundfrage. Metaphysics takes things (whatever is real, whatever has being ${ }^{63}$ as its material object; and then asks about the being that makes them be real. In the traditional reading of Aristotle's metaphysical question (and here I focuse on its ontological moment and prescind from its theological moment) that inquiry unfolds as follows.

1. The material object that metaphysics takes up is things, whatever has being, whatever is real ( $\tau$ ò öv).

2. The formal focus on those things is then articulated by the proviso: insofar as they have

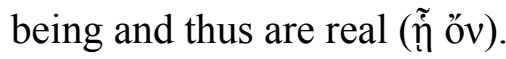

3. Finally, the sought-for outcome of that question is formally indicated as: whatever it is that makes things be real. Depending on the metaphysician, the content that fills out the

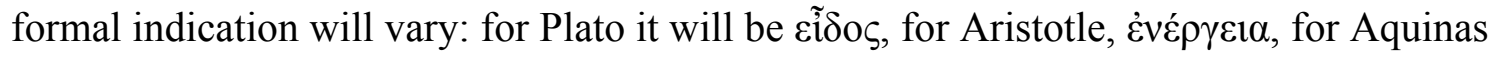
esse or actus essendi; and so on. ${ }^{64}$

\section{METAPHYSICS' LEITFRAGE}

das Befragte: $\quad$ things that are real, i.e., have "being"

das Gefragte: What accounts for them as real?

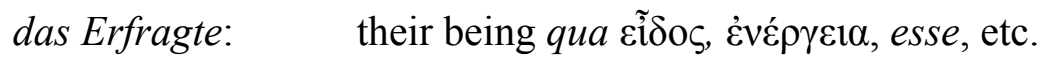

${ }^{63}$ GA 22: 7.14-5 = 5.36: "Es ist, es hat Sein" (Heidegger's italics).

${ }^{64}$ At GA 22: 60.3 = 50.21-2 metaphysics' Erfragtes is formally indicated as: "[Das,] was allein das Seiende selbst in seinem Sein zugänglich macht." Cf. GA 73, 2: 997.2: "esse = quo est." On i $\delta \dot{\varepsilon} \alpha$ as Seiendheit: GA 94: 424.6-7. 
As these formulations show, the metaphysical question is focused decidedly on things, specifically from the viewpoint of why, how, and to what extent they are real. Metaphysics begins with things, then "steps beyond" them to discover what constitutes them as real at all: their being or "being-ness" in a variety of historically changing forms. But finally metaphysics returns to those things with that news. As Aristotle puts it, metaphysics announces "whatever belongs to things in and of themselves" and specifically their "first principles and highest causes." ${ }^{65}$ That is, the question that metaphysics puts to things is: what is their "essence" (their esse-ness), in the broad sense of what lets them be at all. However, the main focus is on the things. Metaphysics is clearly a matter of onto-logy insofar as the operations of questioning and answering (-logy) all bear ultimately on beings (onto-).

On the other hand, Heidegger's meta-metaphysical inquiry takes up where metaphysics leaves off. It takes the very being of things (whatever its historical form) and puts that under the microscope as the subject matter. What about this realness itself, this ov่ ${ }^{\prime} \alpha$ that things "have"?

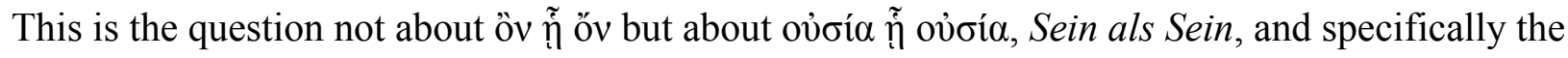
question about what accounts for the fact that there is Sein at all. ${ }^{66}$ Heidegger's question is about "what grounds the inner possibility and necessity" of being and its openness to us. ${ }^{67}$ If we recall that the word "being" always and only refers to what makes beings be real, ${ }^{68}$ we may state Heidegger's basic question in traditional ontological language. (Later I will express it in a more appropriate phenomenological form.)

\footnotetext{
${ }^{65}$ Metaphysics IV 1, 1003a21-2 and 26-7.

${ }^{66}$ GA 14: 86.24-87.1 = 70.9-10: "Sein als Sein, d.h. die Frage, inwiefern es Anwesenheit als solche geben kann." GA 15: $405.30=96.12$ : "Wo und wie west anwesen an?" GA 65: $78.22=$ 62.30: "Die Grundfrage: wie west das Seyn?" GA 88: 9.7: "Wie west das Sein?"

${ }^{67}$ GA 16: 66.15-6: "worin gründet die innere Möglichkeit und Notwendigkeit der Offenbarkeit des Seins."

${ }^{68}$ SZ 9.7 = 29.13: "Sein ist jeweils das Sein des Seienden."
} 


\section{HEIDEGGER'S GRUNDFRAGE IN TRADITIONAL ONTOLOGICAL TERMS}

das Befragte: $\quad$ the very being [of things]

das Gefragte: $\quad$ How is such being possible and necessary?

das Erfragte: [Let "X" formally indicate the sought-for outcome.]

If we postpone for a moment what the heuristic "X" will turn out to be, I am arguing that das Sein in any and all of its incarnations is not the heuristic goal of Heidegger's question, but only its subject matter. The being [of things] is only the Befragtes, whereas the Erfragtes (which as yet remains undecided and is only formally indicated by the " $\mathrm{X}$ ") is whatever will turn out to answer the question: "What makes the very being of things possible and necessary?" Consider the following analogy, which, for all its limitations, may nonetheless get us into the ballpark of Heidegger's question:

\begin{tabular}{|lll|}
\hline & Asking about the kids $\quad$ Asking about their mother \\
das Befragte: & the Smith children & Mrs. Smith \\
das Gefragte: & How did they get here? & How did she get here? \\
das Erfragte: & their mother (= Mrs. Smith) & her mother (= Mrs. Jones) \\
& & \\
& & \\
\end{tabular}

Metaphysics is a bit like asking the question "Who are these children?" and answering it by tracing the kids back to Mrs. Smith. The children are the subject matter of the question, and the inquiry reaches back behind them in the direction of the heuristic Erfragtes, which is: "the mother 
of these kids." This latter phrase is the formal indication of the sought-for answer, an indication that, inasmuch as it is merely formal, does not yet have concrete material content. Eventually the actual content of that formal indication will turn out to be: Mrs. Smith. Fine - but the question is nonetheless geared entirely to defining the children in light of Mrs. Smith.

On the other hand, Heidegger's meta-metaphysical question is a bit like starting with Mrs. Smith herself and considering her not as the mother of the little Smiths (which of course she never ceases to be, even if we bracket that out for a moment) but rather in terms of herself. Mrs. Smith herself now becomes the subject matter, and the new inquiry reaches back behind her in the direction of the heuristic Erfragtes, which is: "the mother of Mrs. Smith." This phrase is merely the formal indication whose material content will turn out to be: Mrs. Jones. Heidegger's Grundfrage is a bit like Mrs. Smith's night out. It asks about Mrs. Smith seen for herself, apart from her relation to the children. And therefore the question goes "behind" Mrs. Smith to her source, the reason why there is a Mrs. Smith at all. And that will turn out to be Mrs. Jones.

This is analogous to what Heidegger means when he says that his effort is "to think Sein without regard to its being grounded in terms of Seiendes" However, the intensifier "itself” (das Sein selbst) can be misleading. It might make one think Heidegger is after Sein in its Really Real Form, the way one might look around a cocktail party ("No, not him, nor him. ..") and then say to one's partner, "There! That's the host himself." This not what Heidegger intends by "being itself." Here we run into a major problem that has confused Heidegger scholarship from the very beginning: the damnable fact that Heidegger uses "das Sein $s e l b s t$ " in two very distinct senses. On the one hand it refers to the Befragtes or subject matter of his question; on the other it is a heuristic device, a merely formal indicator: "being itself" is the heuristic " $X$ " that stands in for the as-yet-unfound answer to that question.

${ }^{69}$ GA $14: 5.32-3=2.12-4$. 


\section{THE TWO MEANINGS OF "DAS SEIN SELBST"}

As the Befragtes it means: the very being [of a thing] as subject matter of the question.

As the Erfragtes it is: $\quad$ a formal indication of whatever will answer the question.

In the first case, the phrase "being itself" refers to what is under investigation, analogous to the way Mrs. Smith, as the Befragtes, was queried for herself and not as the mother of the little Smiths. ${ }^{70}$ But in the second case (and with almost inevitable confusion) Heidegger more frequently uses "being itself" not to name the Befragtes of his question but rather as the Erfragtes, and thus as a heuristic stand-in for, a mere formal indication of, whatever it may turn to make the being of things possible and necessary. In this latter case the philosophical meaning of "being itself" is: "das Wesen des Seins," Woher des Seins, the "whence" of being: "that from which and through which being comes to pass at all. ${ }^{, 72}$ This will turn out to be Ereignis, the appropriation of ex-sistence to its thrownopenness as the clearing. ${ }^{73}$

To confuse "being itself" as the subject matter of Heidegger's question with "being itself" as a formal indication of the answer to that question is a bit like confusing Mrs. Smith with "the mother of Mrs. Smith" - who turns out to be Mrs. Jones. You wouldn't want to confuse mother

70 "Being itself" has this sense at, e.g., SZ 152.11 = 193.31: "nach ihm [= das Sein] selbst"; at GA 40: $183.22=186.17$; etc.

${ }^{71}$ GA 73, 1: 108, my emphasis. GA 14: 141.3-4: “Grundfrage nach dem Wesen und der Wahrheit des Seins."

${ }^{72}$ GA 73, 1: 82.15-6: “das von woher und wodurch . . . das Sein west.” GA 94: 249.5 and .19: "[die] Wesung des Seins."

${ }^{73}$ GA 73, 1: 585.27: “Ereignis führt sich uns zu, in dem es uns dem Da er-eignet." Ibid., 585.19: "Er-eignet uns dem Da," italicized. 
and daughter. That would be a major category mistake . . . and potentially embarrassing.

"Being in and of itself" is what Heidegger is interrogating (befragen) in an effort to discover its "whence," which will turn out to be the clearing that is opened up by the appropriation of ex-sistence. "Appropriation yields the openness, the clearing, within which meaningful things can perdure."74 "Being itself" does not indicate some "higher" form of Being, a Super-Sein that is different from and superior to the plain ol' being-of-beings or beings-in-theirbeingness. Heidegger's goal, rather, was to think Anwesen back to its source in Ereignis ("auf das Ereignis $z u$. . gedacht") ${ }^{75}$ as the indefinable "it" that "gives" the possibility of meaning at all. This move is what Heidegger calls "the return from meaningful presence to Ereignis." ${ }^{, 76}$ And once one gets there, Heidegger says, "there is no more room even for the word Sein."77

Without some such clarification, confusion is virtually evitable, and we can see that confusion at work when Heidegger defines his central topic as "das Sein selbst in dessen Wesen" - "being itself in its own essence." 78 This German phrase brings together both senses of "being itself." The first three words refer to the Befragtes of Heidegger's question, whereas the last three words refer to the Erfragtes.

${ }^{74}$ GA $12: 247.2-4=127.18-9$.

${ }^{75}$ GA 14: 45.29-30 = 37.5-6. See GA 12: 249.30-1 = 129.38-40: "Dagegen läßt das Sein hinsichtlich seiner Wesensherkunft aus dem Ereignis denken."

${ }^{76}$ GA 14:55.8 = 45.32: "Rückgang vom Anwesen zum Ereignen."

${ }^{77}$ GA 15: 365.17-8 = 60.9-10: "ist sogar für den Namen Sein kein Raum mehr."

${ }^{78}$ GA $40: 183.22=186.17$. 


\section{"Das Sein selbst in dessen Wesen"}

\section{In ontological terms:}

Befragtes $=$ das Sein selbst: $\quad$ The very being [of things] is under investigation.

Erfragtes = in dessen Wesen: $\quad$ We seek the essence or whence of such being.

\section{In more appropriate phenomenological terms:}

Befragtes $=$ das Anwesen selbst: $\quad$ Meaningfulness itself is under investigation.

Erfragtes $=$ in dessen Woher: $\quad$ We seek what makes meaningfulness possible at all.

At this point one might well mutter Lasciate ogni speranza voi ch'entrate qui. However, to switch from Dante to Dobson, there is a way out of this Humpty-Dumpty-ism of "When I use a word, it means just what I choose it to mean - neither more nor less." 79 In his later work, especially after 1960, Heidegger expressed himself more clearly: what the formally indicative term das Sein selbst actually refers to is die Lichtung, the clearing, which he designated as the Urphänomen. ${ }^{80}$ The clearing is the always already opened-up "space" that makes the being of things (phenomenologically: the intelligibility of things) possible and necessary. The heuristic $\mathrm{X}$ now has some actual, real content; and what previously was only formally indicated is now materially spelled out and properly named.

Hence this essay's solution to the Humpty-Dumpty-ism of das Sein selbst: From now on I will strictly avoid the term "being itself." Instead, I will call Heidegger's subject matter "meaningfulness" and the sought-for outcome of his inquiry "the clearing."

${ }^{79}$ Carroll, Through the Looking-Glass, chapter 6, 66.21-4.

${ }^{80}$ GA 14: 81.13 = 65.30-1. 
The question now, of course, is: What exactly is this phenomenon called Ereignis that lets meaningful presence come about? The key to understanding Ereignis is to realize that it is the later Heidegger's reinscription of what he had earlier called Geworfenheit, "thrownness," and more fully der geworfene Entwurf, "thrown-openness." Therefore, prior to getting to Ereignis, a brief run-through of what Heidegger was trying to do in Being and Time.

\section{Being and Time's goal was the openness (Lichtung) that allows for meaning at all.}

In the Big Picture, the goal of Being and Time was to identify and explain the openness that makes it possible to take something as this-or-that or as a suitable means to achieve an end, and thus to make sense of it (traditionally, to understand its Sein). ${ }^{81}$ This "open space" went by a series of cognate and mutually reinforcing terms throughout Heidegger's career, among which are Da, Welt, Erschlossenheit, Zeit, Temporalität, Zeit-Raum, Offene, Weite, Gegend, and Zwischen. In his later work, however, all these terms tended to gather around Lichtung, ${ }^{82}$ the intrinsically concealed clearing. ${ }^{83}$

Why does meaning require a "space of openness"? Answer: because our experience of meaning is inevitably discursive. If we stay within Heidegger's phenomenological framework, the argument comes out as follows:

1. To think or act dis-cursively entails "running back and forth" (dis-currere) between a thing and its possible meanings, or between a tool and the task-to-be-done, as one checks out whether the thing actually does have this meaning, or whether the tool is in fact suitable for the task. ${ }^{84}$

${ }^{81}$ GA 9: 131.21-2 = 103.33-5: "Verständnis des Seins (Seinsverfassung: Was- und Wie-sein) des Seienden."

${ }^{82}$ E.g., GA 9: 326.15-6 = 248.37-7: "Die Lichtung des Seins, und nur sie, ist Welt."

${ }^{83}$ GA 87: 99.27-9: Welt and its Welten are intrinsically hidden.

${ }^{84}$ SZ 34:1-4 = 57.25-8: "rekurriert," where Heidegger follows Aquinas, Summa theologiae I, 58, 3, ad 1 and Summa contra gentes, I, 57, 2. 
2. When I take something as this-or-that or as suitable for a task, I (rightly or wrongly) understand the current meaning of that thing for me (ontologically: das jeweilige Sein des Seienden).

3. The "as" or "as suitable for" indicates a possible relation between a thing and its meaning, or a tool and the task; and such a relation requires a "space" between the relata. Hence I can think and act discursively only by metaphorically "traversing the open space" $\$ 5$ between the tool and the task or the thing and its meaning. That "space" is the clearing.

4. But the clearing must be always already operative in order for there to be an "as" or an "as-suitable-for" at all.

5. Hence, the ever-operative, always-thrown-open clearing is what allows for all cases of meaningfulness (ontologically: all instances of das Sein). The thrown-open clearing is thus the "thing itself" of all Heidegger's work.

In Being and Time this clearing is called the $D a$ of $D a$-sein. This word $D a$ should never be translated as "here" or "there" but always as "openness" or "the open" in the sense of that which is thrown-open. "Existence is thrown, brought into its openness but not of its own accord." ${ }^{\text {"So }}$ too Da-sein should not be translated as "being-there," "being-here," or "being t/here." Heidegger

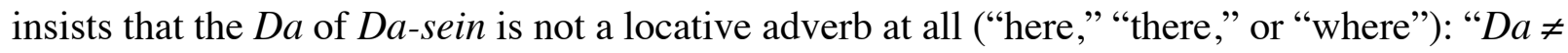
ibi und ubi." ${ }^{, 87}$

"Da-sein" is a key word of my thinking and thus the occasion for major misunderstandings. For me, "Da-sein" does not mean the same as "Here I am!" but rather - if I might express it in a perhaps impossible French - être le-là. And the le-là is precisely'A $\lambda \dot{\eta} \vartheta \varepsilon ı \alpha$ : disclosedness - openness. ${ }^{88}$

\footnotetext{
${ }^{85}$ GA 15: $380.6=68.43:$ "eine offene Weite zu durchgehen." Cf. GA 14: 81.35 and 84.3-4 = 66.19 and 68.9 ; GA 7: $19.12=18.32$.

${ }^{86}$ SZ 284.11-2 = 329.35-6.

${ }^{87}$ GA 71: $211.4=180.30$. Heidegger (2011), 9.27-8: “'Da' nicht demonstrativ (wie 'dort') ontisch, sondern: ekstatisch - dimensioniert."

${ }^{88}$ Heidegger (1964) 182.27-184.3. See Heidegger (1987) 156.33-5 = 120.20-1.
} 
Thus the Da of Dasein

should designate the openness where beings can be present for human beings, and human beings for themselves. ${ }^{89}$

The human being occurs in such a way that he or she is the " $D a$," that is, the clearing of being. ${ }^{90}$

[Exsistence] is itself the clearing. ${ }^{91}$

The clearing: the $D a-i$ is itself existence. ${ }^{92}$

Existence must be understood as being-the-clearing [die-Lichtungsein]. $D a$ is specifically the word for the open expanse. ${ }^{93}$

To be - the clearing - to be cast into the clearing as the open $=$ to-be-the-open. ${ }^{94}$

The same goes for Erschlossenheit, which translates $\dot{\alpha}-\lambda \eta \dot{\vartheta} \varepsilon 1 \alpha$ : dis-closedness, i.e., openness. For Heidegger there are three interrelated levels of disclosedness/openness, which we may designate as $\dot{\alpha} \lambda \hat{\eta} \vartheta \varepsilon 1 \alpha-1, \dot{\alpha} \lambda \hat{\eta} \vartheta \varepsilon 1 \alpha-2$, and $\dot{\alpha} \lambda \hat{\eta} \vartheta \varepsilon 1 \alpha-3$. In reverse order:

$\dot{\alpha} \lambda \eta \dot{\vartheta} \xi 1 \alpha-3$ refers to "correctness," the agreement of a propositional statement with the state of affairs to which it refers: what is traditionally called the correspondence of intellect and thing. But if the intellect is to correspond to it, that thing or state of affairs must

${ }^{89}$ Heidegger (1987) 156.35-157.1 = 120.22-4. See GA 27: 136.13-5 and 137.7-8. ${ }^{90}$ GA 9: 325.20-1 = 248.11-2. See Heidegger $(1987)$ 351.14-7 = 281.31-282.1; GA 14: $35.23=$ 27.33; GA 49: 60.25-7; GA 66: $129.5=109.7-8$; and GA 6:2: 323.13-5 = 218.3-5 (!).

${ }^{91} \mathrm{SZ} 133.5=171.22$.

${ }^{92}$ Heidegger (2011) 9.23. See also GA 3: 229.10-1 = 160.32; and GA 70: 125.12 .

${ }^{93}$ GA 15: 380.11-2 = 69.4-5. Also SZ 147.2-3 = 187.13-4 and GA 66: $100.30=84.11$.

94 GA 69: 101.12: "Die Lichtung - sein - in sie als Offenes sich loswerfen = das Da-sein." 
itself be already dis-closed or opened up as knowable - which means that correspondence depends on

$\dot{\alpha} \lambda \dot{\eta} \vartheta \varepsilon 1 \alpha-2$, the prior, pre-propositional openness or intelligibility of things, which Heidegger initially called "ontic truth." Finally, at the root of the previous two, and making them possible, there is

$\dot{\alpha} \lambda \eta \dot{\eta} \vartheta \varepsilon 1 \alpha-1$, the thrown-open clearing ("openness-prime") that exsistence itself is and that makes possible meaningfulness at all. This is what Heidegger initially called "ontological truth." This uropenness is the clearing in both the early and later Heidegger. ${ }^{95}$

The same goes for Zeit and Temporalität. Heidegger's use of the term "time," especially in his earlier writings, can be misleading. But in his later writings he was clear: this word is only ein Vorname, a preliminary and halting attempt to articulate $\dot{\alpha} \lambda \hat{\eta} \vartheta \varepsilon 1 \alpha-1$, the ur-disclosedness/ openedness that is the clearing. ${ }^{96}$ Zeit and Temporalität are early stand-in terms for die Lichtung. See, for example, "Sein und seiner Lichtung ('Zeit'),"97 "Sein west in der Lichtung der Zeit,",98 "Lichtung der Sichvergerben (Zeit) erbringt Anwesen (Sein)." ${ }^{99}$ See also Heidegger's interpretation of "time and being" as Lichtung und Anwesenheit. ${ }^{100}$ Therefore, in translating and interpreting Zeit and its cognates we would do well to avoid anything that sounds like "time" and "temporality," lest we think Heidegger is still talking about past-present-future. ("The customary representations of time ... will not get at what is sought after in the [basic] question." ${ }^{101}$ Instead, he says, "In Being and Time I have attempted to develop a new concept of time and temporality in

${ }^{95}$ On $\dot{\alpha} \lambda \dot{\eta} \vartheta \varepsilon 1 \alpha-1:$ GA 14: 82.9 =66.26; 85.32-3 =69.21-2. On $\dot{\alpha} \lambda \dot{\eta} \vartheta \varepsilon 1 \alpha-1$ and -2: GA 3: 13.15-7= 8.40-9.1. On $\dot{\alpha} \lambda \dot{\eta} \vartheta \varepsilon 1 \alpha-3$ : SZ 214.24-36 = 257.24-5.

${ }^{96}$ GA 9: $376.11=285.26-7$ and 159 note $\mathrm{a}=123$ note $\mathrm{a} ; \mathrm{GA} 14: 36.11-2=28.20-1$; GA $49: 57.2-$ 3; GA 65: 74.10-1 = 59.20-3; and GA 74: 9.6.

${ }^{97}$ GA $66: 145.25=124.6$. Cf. SZ 408.7 $=460.20-1$.

${ }^{98}$ GA 74: 9.3 .

${ }^{99}$ GA 11: $151.37-8=$ xx.32-3. Cf. ibid., 151.21-2 = xx.25-7.

${ }^{100}$ GA 14: 90.1-2 = 73.1-2. Here Heidegger inverts "being and time" to "time and being," the title projected for SZ I.3.

${ }^{101}$ GA 73, 1: 90.10-12 = 14.37-9. See GA 20: 442.12-4 = 320.3-5. 
the sense of ecstatic openness" 102 - in other words, the "open space" or clearing that makes discursive sense possible.

If Da, Welt, Erschlossenheit, Zeit, and Temporalität are early names for Lichtung, we may ask what sustains this clearing, i.e., what holds it open. Heidegger's answer, early and late, is exsistence. "To exist," he says, "might be more adequately translated as "sustaining a realm of openness." 103 More specifically, in Being and Time what sustains that openness is our structure as projected-open, der geworfene Entwurf - "thrown-openness," with emphasis on the thrownness as our being a priori drawn out and opened up as possibility. The thrown-openness of ex-sistence is not due to a spontaneous initiative on the part of the human will. Rather, it consists in our being always already pulled open (or as Being and Time puts it: stretched open), structurally "made-tostand-out" as possibility (ex + sistere),${ }^{104}$ drawn out ahead of ourselves so that we sustain the $D a$ or Welt that we ourselves existentially are. ${ }^{105}$ In Being and Time the final name for the thrownopenness that sustains the clearing is Zeitlichkeit - again, not to be interpreted as "temporality" with its connotations of past-present-future but rather as the always-already-operative "unfolding" (Zeitigung) of the clearing qua ecstatic openness. ${ }^{106}$

Although Being and Time was to remain a torso, it had already sketched out a response to Heidegger's basic question, one that did not change in its fundamentals, even in the later work. What allows for intelligibility and meaning at all? Answer: the thrown-open clearing that lets us make sense of the things we encounter (i.e., understand their being), whether practically or theoretically.

\footnotetext{
$\overline{102}$ GA 16: 708.9-11 = 45.16-8.

${ }^{103}$ Heidegger (1987) $274.1=218.15$.

${ }^{104}$ GA 94: 281.27.

105 "Pulled" or "drawn out": GA 8: 11.6-11 = 9.13-17 and GA 6:2: 360.12-4=249.35-6.

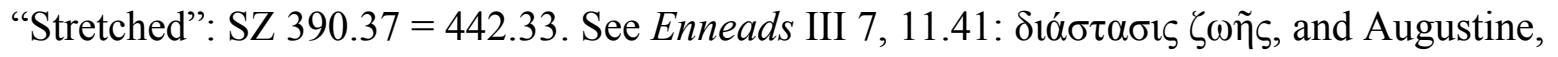
Confessions, XI 26.33: distentio animi.

${ }^{106}$ Zeitigung or Sich-zeitigung should never be translated as "temporalization" (which means nothing) but always in terms of unfolding or emergence. "Zeitigung als Sich-zeitigen ist Sichentfalten, aufgehen und so erscheinen," Heidegger (1987) 203.7-8 = 158.10-1.
} 
4 Ereignis - the appropriation of existence to sustaining the clearing - is the later Heidegger's reinscription of thrown-openness.

The key to understanding Ereignis is to realize that it is the later Heidegger's reinscription of what he had earlier called Geworfenheit, "thrownness" and more fully der geworfene Entwurf, “thrown-openness." (Why "thrown-openness? Answer: What Da-sein is thrown into is its own Existenz, but into Existenz as the open clearing.) ${ }^{107}$

We saw that Heidegger's basic question is: What makes the meaningful presence of things possible at all? If the early Heidegger's response was our a priori thrown-openness as the clearing, the later Heidegger's answer was the same: What makes meaningfulness possible is our structural appropriation to holding open the "space" for discursive intelligibility. Thrownness and appropriation are identical, simply earlier and later names for the same existential structure. We can see that identity from the way the later Heidegger frequently equates the two by placing them in apposition to each another.

die Er-eignung, das Geworfenwerden

"being appropriated, becoming thrown"108

geworfener ...d.h. er-eignet

"thrown ..., that is, appropriated"109

Das Dasein ist geworfen, ereignet

"Existence is thrown, [i.e.,] appropriated."110

${ }^{107}$ SZ 276.16-7 = 321.11 with SZ 133.5 = 171.22.

${ }^{108}$ GA $65: 34.9=29.7$.

${ }^{109}$ GA $65: 239.5=188.25$.

${ }^{110}$ GA 65: 304.8 = 240.16. See ibid., 252.23-5 = 199.3-4. Also GA 9: 377, note $\mathrm{d}=286$, note d: "Geworfenheit und Ereignis." 
We see it again in the equivalence of Heidegger's earlier and later formulations for what existence is called to "take over":

$$
\begin{aligned}
& \text { die Übernahme der Geworfenheit } \\
& \text { "taking over one's thrownness"111 } \\
& \text { die Über-nahme der Er-eignung } \\
& \text { "taking over one's being appropriated"112 }
\end{aligned}
$$

How to translate Ereignis? In ordinary German the word means "event." However, in establishing his own technical meaning of Ereignis, Heidegger repeatedly refused its translation as "event" (hence even as "event of appropriation"). He consistently argued against understanding Ereignis as any kind of happening.

What the term Ereignis names can no longer be represented by way of the current meaning of the word, for in that meaning Ereignis is understood as an event and a happening .... ${ }^{113}$

Here the term Ereignis no longer means what we would otherwise call a happening, an occurrence. ${ }^{114}$

Ereignis . . . cannot be represented either as an event or a happening. ${ }^{115}$

Nevertheless let us ask: Is appropriation an event? Is it a unique moment in a temporal continuum, with a before and an after? Does it happen at certain distinguishable times, so that we

\footnotetext{
${ }^{111} \mathrm{SZ} 325.37=373.14-5$.

${ }^{112}$ GA 65: 322.7-8 = 254.36-7. GA 94: 337.7-8: "ein Zurückwachsen in das Tragende der Geworfenheit."

${ }^{113}$ GA 14: 25.33-26.1 = 20.29-33: Vorkommnis, Geschehnis.

${ }^{114}$ GA 11: 45.19-20 = 36.18-9. Geschehnis, Vorkommnis. The German text adds a note: [nor as] "eine Begebenheit," an event.

${ }^{115}$ GA 12: 247.9-10 = 127.25-7: Vorkommnis, Geschehen.
} 
can say "Now it is in effect, whereas before it was not"? No, Ereignis is much more than an event: it is a fact, that which is always already done (factum). Appropriation is that which "is already operative in our case, even before we were." 116 What is more, it is the fact, the "Urfaktum" or "thing itself," without which there are no other facts, events, or happenings in the human realm. ${ }^{117}$ This Fact (and for a moment we capitalize it to show its capital role in human being) both determines and is coterminous with ex-sistence, without being supervenient to or separable from it. But what is the Fact that the word "appropriation" is trying to express? It is simply that, without any discernible reason, we are thrown open in such a way that we are always already "brought ad proprium" (ad + propri-ated), brought into our "proper" as the clearing. "Ap-propriation" means that we have always already been "released into our ownness," our essence: the clearing. ${ }^{118}$ And that proper ownness Without this primordial and ever on-going Fact, nothing human happens; and yet in itself it is not a happening but the presupposition of all happenings: $\tau$ ò

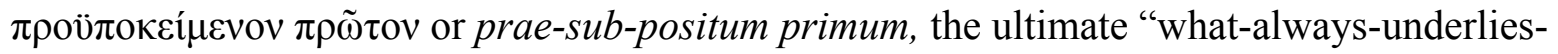
beforehand." 119 It is always already operative wherever there is existence. To be human is to be structurally thrown into sustaining the space-for-intelligibility opened up by one's (finite and mortal) appropriation.

This utterly unique phenomenon is what Heidegger called the Gegenschwung or oscillation that is the relatedness of Da-sein/Lichtung. ${ }^{120}$ But this means that the word "relatedness" must be understood "in a wholly different way" - specifically in the sense that "human being, in its essence, is needed [for the clearing] and belongs . . in this need that claims it."121 "The relatedness, however, is not [something] stretched between the clearing and man. ...

${ }^{116}$ GA 73, 1: 820.11-4: "eh wir waren, schon bei uns gewesen." GA 11: 20.23-7 = 73.10-5: "immer schon in einer solchen Entsprechen." GA 13: 242.8-9: das Unzugangbare to which "wir Sterbliche / anfänglich ge-eignet sind."

117 See GA 26: 270.10 = 209.7: "Urfaktum."

${ }^{118}$ GA 12: 249.5-6 = 129.13: “in sein Eigenes entläßt.” See ibid., 248.6-7 = 128.19-20; 248.15-6 =128.29-129.1; and GA 14: 28.14-7=23.11-2. GA 77: 124.5 = 80.31: "Wir sind der Gegnet geeignet."

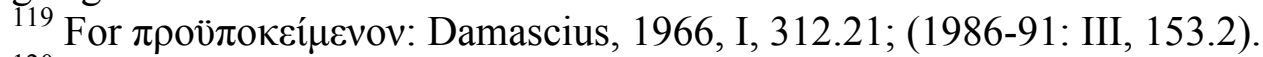

${ }^{120}$ For Gegenschwung/oscillation and Ereignis (unfortunately translated as "event") see GA 65 : $251.24-5=198.14 ; 261.26=206.3 ; 262.7-8=206.15-6 ; 286.31-287.1=225.19-21 ; 351.22=$ 277.39-40; and 381.26-7 = 301.29-30.

${ }^{121}$ Respectively GA 12: 118.21-3 = 32.13-4: "ganz anders hören," and 119.8-10 = 32.26-8: 
The relatedness is the clearing itself, and man's essence is this same relatedness." ${ }^{\text {"122 }}$ The clearing and ex-sistence are not two separate factors, but a unique and undividable "unitary phenomenon" $" 123$ that found its earliest expression in the term In-der-Welt-sein, man's a priori status as sustaining the clearing-for-meaningful-presence. Moreover, this oscillating sameness is precisely what Heidegger means by "the turn" in its primary and proper sense, which he called "die im Ereignis wesende Kehre," the turn operative in appropriation. ${ }^{124}$ That is: this turn - the Gegenschwung as the man/clearing oscillation - is always-already operative (west) due to appropriation. Heidegger sometimes expresses this oscillation as the clearing's "need" of exsistence to hold the clearing open, and as ex-sistence's "belonging" to the clearing in the sense of holding it open. ${ }^{125}$ This reci-proci-ty (back-and-forth-ness) of need and belonging is what Heidegger means by Ereignis, "the ap-propri-ating that earlier I called 'being.",126

In identifying the man/clearing oscillation as the "primary and proper" sense of the Kehre, I am contrasting it with Heidegger's 1930s shift from a transcendental to a seinsgeschichtlich approach. That shift he called not "the turn" but simply a change in approach to his question (die Wendung im Denken). ${ }^{127}$ Many scholars still think, incorrectly, that this shift in approach is the primary and proper sense of the Kehre. However, Heidegger speaks of the oscillation-operativein-appropriation as "the hidden ground of all other subordinate turns," 128 including that shift of approach in the 1930s. That is why Heidegger could tell William J. Richardson in his letter of April, 1962:

First and foremost the Kehre is not a process that took place in my thinking and questioning. [That process is the shift of approach in

\footnotetext{
"gebraucht, gehöre ... in einen Brauch, der ihn beansprucht."

${ }^{122}$ GA 73, 1: 790.5-8: "Der Bezug ist jedoch nicht zwischen das Seyn und den Menschen eingespannt. . . . Der Bezug ist das Seyn selbst, und das Menschenwesen ist der selbe Bezug." ${ }^{123}$ SZ 53.12 = 78.22: "ein einheitliche Phänomen."

${ }^{124}$ GA $65: 407.8=322.33$.

${ }^{125}$ GA 65: 251.24-5 = 198.14: "Dieser Gegenschwung des Brauchens und Zugehörens macht das Seyn als Ereignis aus." GA 94: 448.21-2: "Der andere Gott [= die Wahrheit des Seins: GA 65: 35.2 and 308.25] braucht uns"; and ibid., 449.10-4.

${ }^{126}$ GA 81: 209.8 .

${ }^{127}$ GA 11: $150.19=$ xviii.27. One of the clearest statements on this is GA 74: 8.5-28.

${ }^{128}$ GA 65 : 407.8-11 = 322.33-4.
} 
the 1930s.] . . The turn is operative within the issue itself. It is not something I came up with, and it does not pertain just to my thinking. 129

In other words, the structural fact of the man/clearing oscillation - or rather, Heidegger's insight into that fact - is what brought about the shift of approach in the 1930s, and not vice versa. This oscillation is the primary and proper meaning of "die Kehre."

In thrown-openness or appropriation, what gets thrown open or appropriated (geworfen, ereignet) is human being itself. ${ }^{130}$ However, we must be careful - more careful than Heidegger himself was - in articulating that point, lest we end up hypostasizing Appropriation or Being Itself into an ontological Super-Something, with a life of its own and agency to boot, that does the appropriating and throwing. ${ }^{131}$ There is no "reason why" ex-sistence is thrown-open or appropriated: it is ohne Warum. I suggest we drop all talk of man being "thrown or appropriated by ...," if only to purge, once and for all, the crypto-metaphysics that has colonized Heidegger scholarship in recent years (with quite a bit of help, one must admit, from Heidegger itself). Such fatal hypostasization and quasi-personalization of Being Itself, whether by the Master or his disciples, turns Heidegger's work into a parody of itself. Think of the pathos of "Being is still waiting for the time when It itself will become thought-provoking to the human being." ${ }^{132}$ Or the silliness of "Being as such is not yet awake in such a way that it might catch sight of us from out of its awakened essence." 133 Or Heidegger's hyperbolic claim about Being's “ownership" of us as if we were its "property" (Eigentum). ${ }^{134}$ This is less dormitat Homerus and more inebriatus est Noe. With texts like these it's best to take Virgil's advice to Dante: Non ragionam di lor ma quarda e passa.

${ }^{129}$ GA 11: 149.29-150.1 = xviii.1-8, my emphasis in the ET.

${ }^{130}$ GA 12: 249.1-2 = 129.9. GA 94: 448.31: “das Er-eignis des Daseins, wodurch dieses dann geeignet wird." Also GA 14: 28.18-9=23.15-7.

${ }^{131}$ GA 9: $442.21=334.21$ : “zu einem phantastischen Weltwesen hypostasieren." Cf. GA 73, 2: 975.22-3: "als Etwas für sich Vorhandenes."

132 GA 9: $322.30-1=246.15-6$.

${ }^{133}$ GA $10: 80.29-30=54.11-3$.

${ }^{134}$ GA $65: 263.14=207.16$. 


\section{Appropriated thrown-openness, as the clearing, is intrinsically hidden.}

What to make of Heidegger's claim that being itself withdraws itself from us, hides itself, and even refuses itself to us? ${ }^{135}$ Such claims are among the most blatant of Heidegger's frequent and unhelpful hypostasizations and personifications of "Being." Let us ask: What is it that hides? And what does the hiding consist in?

Once we realize that, as a phenomenologist, Heidegger interprets Sein, in all of its incarnations, as the intelligibility of things, we see that it cannot be Sein/meaningfulness that is intrinsically concealed. Rather, what is hidden is that which makes being/meaningfulness possible at all: our thrown appropriation to sustaining the clearing. But how and why does Heidegger argue that this thrown-open clearing is intrinsically hidden?

First of all, as regards rhetoric: Let us avoid the quasi-personalization of the clearing that insinuates itself through the use of the faux reflexive: "The clearing hides itself." In this case verb forms like sich entziehen and sich verbergen are to be read as "The clearing is withdrawn, is hidden" instead of "The clearing ups and hides itself." (Compare etwas zeigt sich: something shows up.) Secondly, as regards substance: The clearing is intrinsically hidden precisely because it is the presupposition of all human activity, including all questioning and knowing, all searching for reasons. Consequently we will never get an answer to the question "What possibilizes that which possibilizes everything?" As Heidegger puts it: "There is nothing else to which appropriation could be led back or in terms of which it could be explained."136 Appropriation is "what originally makes everything possible," analogous to the Good in Plato. ${ }^{137}$ It is that behind which we cannot go without contradicting ourselves.

Trying to explain the presupposition of all explaining is a fool's errand. ${ }^{138}$ It traps us in a petitio principii, a begging of the question - in this case, not realizing that we are already wrapped

${ }^{135}$ Passim. E.g., GA 66: 203. 10-1 = 178.28-9; GA 94: 428.8: etc.

${ }^{136}$ GA $12: 247.12-3=127.28-30$.

${ }^{137}$ GA 22: 106. 32 = 87.32. See Enneads VI.9.11.2-3 and VI.7.40.51-2 (Henry-Schwyzer).

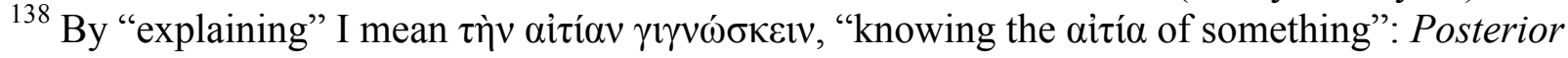


up from the outset in what we are attempting to find. ${ }^{139}$ Heidegger does say that "the petere principium, the reaching out to the supporting ground [= the clearing], is the only move that philosophy ever makes." ${ }^{\prime 140}$ But what he means is that true philosophical thinking actively presupposes this supporting ground by electing to leave it in its unknowability (its "intrinsic hiddenness") rather than attempting to get behind it to an alleged cause. The unknowability of the why and wherefore of the appropriated/thrown-open clearing is what Heidegger finally means by facticity, which he designates as the "mystery" located at the heart of existence: "das Geheimnis des Daseins," 141 "das vergessene Geheimnis des Daseins." "This is what he has in mind when he says: "Der Entzug aber ist des Da-seins"143 (the "withdrawal" goes with the very nature of exsistence). The best Heidegger can do in discussing this mystery is to say Es gibt Sein. The es refers to appropriated thrown-openness, and that is as far back as we can go in discovering what makes possible ( $g i b t$ ) the finite intelligibility (Sein) that we are ineluctably bound up with. As Heidegger wrote to William J. Richardson:

If instead of "time" we substitute "the intrinsically concealed clearing [that is proper to meaningful] presence, then being is determined from out of the thrown-open domain of time.... The intrinsically concealed clearing (Zeit) brings forth presence (Sein). ${ }^{144}$

Because it is intrinsically hidden - unable to be known in its why-and-wherefore - the appropriation of ex-sistence to its proprium (namely, to sustain the clearing) has been overlooked and "forgotten" in all of metaphysics. It is certainly not the being of things (Sein) that metaphysics has forgotten. Philosophers over the centuries have written reams on such being, beginning with Aristotle's Metaphysics. What Heidegger means by his ill-named shorthand term

Analytics I 2, 71b10-1. See "rerum cognoscere causas": Virgil, Georgics II, 490, repeated in the tondo of Rafael's "School of Athens."

${ }_{139}$ Prior Analytics II 16, 64b28.

${ }^{140}$ GA 9: $244.32-3=187.28-9$.

${ }^{141}$ GA $9: 197.26=151.9$.

${ }^{142}$ GA $9: 195.23=149.28$. Cf. GA 10: $126.27-9=85.17-8$.

${ }^{143}$ GA $65: 293.9=231.8-9$.

${ }^{144}$ GA 11: $151.21-2$ and $.27-8=x x i .25-7$ and 32-3. "Thrown-open domain": Entwurfbereich. Cf. GA 9: $201.31=154.13$. 
"the forgottenness of being" (Seinsvergessenheit) is the overlooking of what makes being possible. $^{145}$

In similar fashion the problem of being-hiding-itself is dissolved once we remember that the phrase "being itself" does not refer to some Higher Form of Being (higher than the being of beings) but is simply the formal indication of the "whence" of being, i.e., that which allows for the being of beings at all. ${ }^{146}$ This helps us understand some of the later Heidegger's typical but less than translucent sentences. For example, he writes that being (Seyn, often translated by the barbaric "beyng")

refuses itself and thus hides itself as refusal ... for the sake of the gifting [Schenkung]."147

A periphrastic translation, minus the false personalization, might say: Insofar as the appropriated clearing ("beyng") is intrinsically hidden, we cannot know why and to what end it is the "giving" or origin of all meaningfulness. - Or similarly:

What if being itself [das Seyn selbst $]$ were self-withdrawing and occurred as the denying [of itself to us]? Would such refusal be something empty and void? Or would it be the highest form of gifting? ${ }^{148}$

Translation: Although appropriation-to-sustaining-the-clearing is unexplainable ("intrinsically hidden"), it is not nothing. Rather, it is the primordial source - the "gifting" - of the possibility of meaningfulness. - Or again:

${ }^{145}$ Re ill-named shorthand: Compare, for example, Heidegger's condensation of "the question of the intelligibility of being" into "the question of being" in the titles to the first four sections of SZ. At SZ 26.38 = 49.17-18 he reduces "the question of the intelligibility of being" to the question "Was heißt 'Sein'?" Note the ambivalence at ibid. 26.7-10=49.24-7.

${ }^{146}$ On the forgottenness of the essence of being: GA 79: 53.27-8 = 51.6-7: "Vergessenheit seines [= des Seins] Wesens."

${ }^{147}$ GA $66: 200.32-4=176.35-7$.

${ }^{148}$ GA $65: 246.17-9=194.11-2$. See ibid., 293.16-7 = 231.15-6; and GA 10: 81.15-7 = 54.29-31. 
Being itself [das Sein selbst] withdraws itself. But as this withdrawal, being is precisely the relatedness that claims the essence of man as the abode of being's arrival. ${ }^{149}$

That is: The appropriated clearing, as the intrinsically hidden source of meaningfulness, cannot be comprehended in and for itself. But as intrinsically hidden, it "claims" ex-sistence as the place where meaningfulness occurs. - Or in a passage that may not need paraphrasing:

That which is to be thought turns away from us. It withdraws from us. But how can we have the least knowledge of something that is withdrawn from the outset? How can we even give it a name? Whatever withdraws refuses to arrive. But withdrawing is not nothing. Withdrawal is appropriation. [Entzug ist Ereignis.] In fact, what withdraws may even concern and claim us more essentially that all the meaningful things that strike and touch us. ${ }^{150}$

Or finally, in a simple phrase: die Verweigerung als Schenkung. ${ }^{151}$ That is: appropriation, as intrinsically unknowable in its why and wherefore, is what gives us the gift of the meaningful presence of things.

Reading Heidegger as a phenomenologist whose subject matter was meaningfulness obviates the naïve realist interpretations of being that have recently proliferated in Heideggerscholarship, and it opens up his texts to a new and fruitful dialogue with other philosophical discourses. Furthermore, reading his final goal as the source of meaningfulness frees his work from the false hypostasization of "Being Itself" that plagues the current scholarship, and it brings new clarity to the relation of the early and later Heidegger.

${ }^{149}$ GA $6: 2: 332.25-8=225.22-4$. See ibid., 360.12-4 = 249.35-6.

${ }^{150}$ GA 8: $10.26-32=8: 33-9.5$, my emphasis.

${ }^{151}$ GA $65: 241.17-8=190.18-9$. See GA 66: 200.31-4 = 176.34-7. 
Of course the final final goal of Heidegger's thinking was not theoretical-philosophical but existentiel-personal. Heidegger's philosophy, as one might hope all philosophy would be, was not just about knowing something, getting the answer to a question, no matter how profound that question might be. In the spirit of what we might call Greek "existential wisdom," his philosophy was also and above all a protreptic to self-transformation. ${ }^{152}$ On his first day of teaching after the Great War he urged his students, in the words of the German preacher Angelus Silesius (162477): Mensch, werde wesentlich! "Become what you essentially are!" (which he coupled with Jesus' challenge, “Accept it if you can!”). ${ }^{153}$ Eight years later, in Being and Time he echoed the same exhortation, this time in the words of Pindar: Werde, was du bist! "Become what you already are!" $" 154$ Again, in mid-career (1938) he told his students:

Over and over we must insist: In the question of "truth" as posed here, what is at stake is not only an alteration in the traditional conception of "truth". . . Rather, what is at stake is a transformation in man's being. ${ }^{155}$

Finally, therefore, the theoretical path and the protreptic path become one and the same in Heidegger's work. His single-minded task remained that of explicating existence so as to find its ground, which turns out to be no ground at all but a radical thrown-openness that he urges us to embrace and live out of. We may say, therefore, that throughout the half-century of his career he did nothing but pursue the command inscribed on the Temple of Apollo at Delphi: $\gamma \nu \tilde{\omega} \theta \imath$ $\sigma \varepsilon \alpha v \tau o ́ v$, "Know yourself" - which he glossed as "The question of ex-sistence is clarified only by existing."

END

\footnotetext{
152 GA 94: 5.17: "Der Mensch soll zu sich selbst kommen!" See ibid., 16.12-3.

${ }^{153}$ Literally: "Become essential!" GA 56/57: 5.34-5 = 5.14-5; Matthew 19:12.

${ }^{154}$ SZ 145.41 = 186.4. Pindar, Pythian Odes, II, 72 (Farnell, 1932, III, 56).

${ }^{155}$ GA 45: 214.15-8 = 181.5-8. See GA 94: 259.20-1: "Die Umwälzung zum Da-sein . . . mein einziger Wille."

${ }^{156}$ Respectively Protagoras $342 \mathrm{~b} 3$ and SZ 12.30-1 = 33.8-9.
} 


\section{References}

\section{The Gesamtausgabe volumes cited, along with their English translations}

These follow the rubrics in "A Heidegger Bibliography: The Gesamtausgabe Texts and their Current Translations," which appears in Continental Philosophy Review, 47, 2 (2014).

\section{Other texts}

Aquinas, Thomas. S. Thomae de Aquino, Omnia opera. http://www.corpusthomisticum.org/iopera.html

Aristotle. Aristotelis opera. Ed. Academia Regia Borussica (Immanuel Bekker et al.), 4 vols.

Augustine. The Confessions of Augustine, an electronic edition. http://www9.georgetown.edu/faculty/jod/conf/

Carroll, Lewis (Dobson, Charles). 1920; originally 1871. Through the Looking Glass. Cincinnati: Johnson and Hardin.

Damascius. 1966 (1986-91). Dubitationes et solutiones de primis principiis, in Platonis Parmenidem. Ed. Carolus Aemelius Ruelle, Paris, 1889; reprinted, Amsterdam: Adolf M. Hakkert, 2 vols. (In another edition: 1986-1991. De Principiis in Traité des premièrs principles. Ed. Leendert Gerrit Westerink, tr. Joseph Combès, 3 vols., Paris: Les Belles Lettres.)

Farnell, Lewis Richard. 1932. The Works of Pindar. London: Macmillan, 3 volumes.

Gurwitsch, Aron. 1947. Le Cogito dans la Philosophie de Husserl: Gaston Berger. Philosophy and Phenomenological Research, VII, 4, 649-54. 
Haugland, John. 2000. Truth and finitude: Heidegger's transcendental existentialism. In Heidegger, Authenticity and Modernity: Essays in Honor of Hubert L. Dreyfus, 2 volumes. ed. Mark Wrathall and Jeff Malpas. Cambridge: MIT Press, 4, 43-77.

Heidegger, Martin. 1964. Lettre à Monsieur Beaufret (23 novembre 1945). In Martin Heidegger, Lettre sur l'humanisme, ed. and trans. Roger Munier, new, revised edition. Paris: Aubier, Éditions Montaigne, 180-184.

Heidegger, Martin. 1987. Zollikoner Seminare. Protokolle-Gespräche-Briefe, ed. Merdard Boss. Frankfurt am Main: Vittorio Klostermann. ET Zollikon Seminars: ProtocolsConversations - Letters. 2001. Ed. Medard Boss, trans. Franz Mayr and Richard Askay. Evanston: Northwestern University Press.

Heidegger, Martin. 2011. Die "Seinsfrage” in Sein und Zeit. Heidegger Studies 27, 9-12.

Husserl, Edmund. 1968. Phänomenologische Psychologie (Husserliana IX), ed. Walter Biemel. The Hague: Nijhoff.

Husserl. 1997. Husserl: Psychological and Transcendental Phenomenology and the Confrontation with Heidegger (1927-1931). Thomas Sheehan, and Richard Palmer, eds. and trans. Dordrecht: Kluwer.

Locke, John. 2003. Two Treatises of Government and A Letter Concerning Toleration, ed. Ian Shipiro. New Haven: Yale University Press.

Plato. 1902. Platonis opera. Ed. John Burnet. Oxford: Clarendon, 5 vols.

Plotinus. 1951. Plotini opera. Ed. Paul Henry and Hans-Rudolf Schwyzer. Paris: Desclée de Brower, Brussels: L’Édition Universelle, 3 vols. 
